\title{
Lactobacillus ozensis sp. nov., isolated from mountain flowers
}

Correspondence

Shinji Kawasaki

kawashin@nodai.ac.jp

\author{
Shinji Kawasaki, ${ }^{1}$ Kana Kurosawa, ${ }^{1}$ Madoka Miyazaki, ${ }^{1}$ Mitsuo Sakamoto, ${ }^{2}$ \\ Moriya Ohkuma ${ }^{2}$ and Youichi Niimura ${ }^{1}$
}

\author{
${ }^{1}$ Department of Bioscience, Tokyo University of Agriculture, 1-1-1 Sakuragaoka, Setagaya, Tokyo \\ 156-8502, Japan \\ ${ }^{2}$ Microbe Division/Japan Collection of Microorganisms, RIKEN BioResource Center, Wako, Saitama \\ 351-0198, Japan
}

Five strains (Mizu2-1 ${ }^{\top}$, Gon2-7, Koba6-1, Koyu2-2 and Miya2-2) of lactic acid bacteria (LAB) were isolated from flowers in Oze National Park, Japan, using anaerobic cultivation. The five isolates were found to share identical 16S rRNA gene sequences. The isolates exhibited low levels of $16 \mathrm{~S}$ rRNA gene sequence similarity to known LAB; the closest recognized relatives of strain Mizu2-1 ${ }^{\top}$ were the type strains of Lactobacillus kunkeei (94.9\%), Lactobacillus kefiri (94.1\%) and Lactobacillus buchneri (93.9\%). Comparative analyses of rpoA and pheS gene sequences demonstrated that the novel isolates did not show significant relationships to other Lactobacillus species. The strains were Gram-stain-positive, catalase-negative and heterofermentative. Anaerobic growth was better than aerobic growth. The isolates utilized a narrow range of carbohydrates as sources of carbon and energy, including glucose and fructose. On the basis of phenotypic characteristics and phylogenetic data, the isolates represent a novel species of the genus Lactobacillus, for which the name Lactobacillus ozensis sp. nov. is proposed. The type strain is Mizu2-1 ${ }^{\top}\left(=\mathrm{JCM} 17196^{\top}=\mathrm{DSM} 23829^{\top}\right)$.
During our studies on the distribution of anaerobes in flowers, we have isolated several species of lactic acid bacteria (LAB) from mountain flowers in Japan. We recently reported the isolation of a novel LAB, Lactobacillus floricola, from a mountainous area (Kawasaki et al., 2011). L. floricola showed quite low 16S rRNA gene sequence similarity to known $\mathrm{LAB}$, and also showed a narrow range of carbohydrate utilization, using only glucose and fructose. Here, we report the isolation of further isolates that exhibit low 16S rRNA gene sequence similarity to known $\mathrm{LAB}$ and show a narrow range of carbohydrate utilization. During the course of our investigations of anaerobes in flowers from several mountainous areas in Japan since 2006, the novel species described in this study has been isolated only from the area of Oze National Park.

Flowers were collected from Oze National Park in 20082009. Flower samples were collected using autoclaved

\section{Abbreviation: $L A B$, lactic acid bacteria.}

The GenBank/EMBL/DDBJ accession numbers for the 16S rRNA gene sequences of strains Mizu2- $1^{\top}$, Koba6-1, Koyu2-2, Miya2-2 and Gon2-7 are AB572588-AB572592, respectively. Those for the partial rpoA and pheS gene sequences of strain Mizu2- $1^{\top}$ are AB574477 and AB574478.

Five supplementary figures are available with the online version of this paper. forceps and transferred immediately to sterile tubes. Bacteria were cultivated on MRS agar (Difco) containing $5.0 \mathrm{~g}$ calcium carbonate and $15 \mathrm{~g}$ agar $1^{-1}$ at $20-30{ }^{\circ} \mathrm{C}$ under anaerobic conditions. After isolation, strains were maintained in MRS broth. The origins of the isolates are shown in Supplementary Fig. S1. The proposed type strain Mizu2-1 ${ }^{\mathrm{T}}$ was isolated from a flower of Inula ciliaris var. glandulosa, a chrysanthemum (Japanese common name, oze-mizugiku), that was collected in August 2008. A large number of colonies $\left(10^{4}-10^{8}\right.$ colonies per flower) were obtained, and the 16S rRNA gene sequences of randomly selected colonies suggested that these isolates represent the most abundant species in each flower (data not shown).

Morphological, physiological and biochemical characteristics were determined according to Okada et al. (1992), Holdeman et al. (1977) and Gerhardt et al. (1981), as described previously (Kawasaki et al., 2011). Lactobacillus buchneri NRIC $1040^{\mathrm{T}}$, L. kefiri NRIC $1693^{\mathrm{T}}$, L. kunkeei DSM $12361^{\mathrm{T}}$, L. floricola NRIC $0774^{\mathrm{T}}$ and L. fructivorans NRIC $0224^{\mathrm{T}}$ were used as reference strains in this study. Carbohydrate fermentation tests were conducted in modified MRS broth containing $0.5 \%(\mathrm{w} / \mathrm{v})$ of various carbohydrates, $1 \%$ proteose peptone, $0.1 \%$ beef extract, $0.5 \%$ yeast extract, $0.02 \% \mathrm{MgCl}_{2}, 0.2 \% \mathrm{~K}_{2} \mathrm{HPO}_{4}$ and $0.005 \% \mathrm{MnSO}_{4}$. Acid production from carbohydrates was also tested by using the API 50CHL system (bioMérieux) in 
triplicate according to the manufacturer's instructions. DNA G $+\mathrm{C}$ content determination was carried out according to Mesbah et al. (1989). Sequences of the 16S rRNA genes of the isolates were determined using primers $27 \mathrm{~F}$ ( $5^{\prime}$ GAGTTTGATCCTGGCTCAG-3'; Escherichia coli positions 8-27) and 1525R (5'-AGAAAGGAGGTGATCCAGCC-3'; positions 1525-1545) (Lane et al., 1985). The rpoA and pheS gene sequences for strain Mizu2 $-1^{\mathrm{T}}$ were amplified by PCR with primers rpoA-21F (5'-ATGATYGARTTTGAAAAACC-3') and rpoA-23R (5'-ACHGTRTTRATDCCDGCRCG$\left.3^{\prime}\right)$ and pheS-21F (5'-CAYCCNGCHCGYGAYATGC-3') and pheS-23-R (5'-GGRTGRACCATVCCNGCHCC-3'), respectively (Naser et al., 2005; Chao et al., 2010).

The closest relatives of the isolates were determined by performing a database search and the sequences of the most closely related strains were retrieved from the NCBI database. Multiple alignments of the sequences were carried out using the program CLUSTAL_x, version 2.0 (Thompson et al., 1997). Distance matrices for the aligned sequences were calculated using the two-parameter method of Kimura (1980). The neighbour-joining method (Saitou \& Nei, 1987) was used to construct a phylogenetic tree. The robustness of individual branches was estimated by bootstrapping with 1000 replicates (Felsenstein, 1985). Phylogenetic trees were also constructed using the maximum-likelihood (Cavalli-Sforza \& Edwards, 1967) and maximum-parsimony (Kluge \& Farris, 1969) methods by using PHYLIP version 3.65 (Felsenstein, 2005). The 16S rRNA gene sequences of the isolates were compared, and the sequence of Mizu2$1^{\mathrm{T}}$ was used to search for sequence similarities within the database. Approximately $1500 \mathrm{bp}$ of the $16 \mathrm{~S}$ rRNA gene sequences (approx. $400 \mathrm{bp}$ for the rpoA gene and $350 \mathrm{bp}$ for the pheS gene) of the isolates were used to construct phylogenetic trees.

The 16S rRNA gene sequence of Mizu2- $1^{T}$ showed low sequence similarity to known species of LAB: all similarities were less than $95 \%$, and the closest known relatives were the type strains of Lactobacillus kunkeei (94.9\%), L. kefiri (94.1\%) and L. buchneri (93.9\%). The isolates clustered most closely with L. kunkeei (Edwards et al., 1998) using the neighbour-joining (Fig. 1), maximum-parsimony (Supplementary Fig. S2) and maximum-likelihood (Supplementary Fig. S3) methods. These sequence similarities are significantly lower than those recommended for species differentiation (97\%; Stackebrandt \& Goebel, 1994). Therefore, DNA-DNA hybridization between the isolates and known LAB was not carried out. Similarities among the $r p o A$ and pheS gene sequences of strain Mizu2 $-1^{\mathrm{T}}$ and the closest neighbouring species ranged from 78 to $85 \%$ and 78 to $82 \%$, respectively. On the basis of neighbour-joining analysis of rpoA and pheS gene sequences, the novel strain did not belong to any known species (Supplementary Figs S4 and S5). Similar topologies were obtained by the minimum-evolution and maximum-parsimony methods (not shown). The DNA G $+\mathrm{C}$ content of strain Mizu2-1 ${ }^{\mathrm{T}}$ was $41 \mathrm{~mol} \%$.

The 16S rRNA gene sequence of strain Mizu2- $1^{\mathrm{T}}$ exhibited $100 \%$ identity to those of the other isolates. To differentiate them, isolates Mizu2-1 ${ }^{\mathrm{T}}$, Gon2-7, Koba6-1, Koyu2-2 and Miya2-2 were analysed by randomly amplified polymorphic DNA-PCR (RAPD-PCR) according to the method of

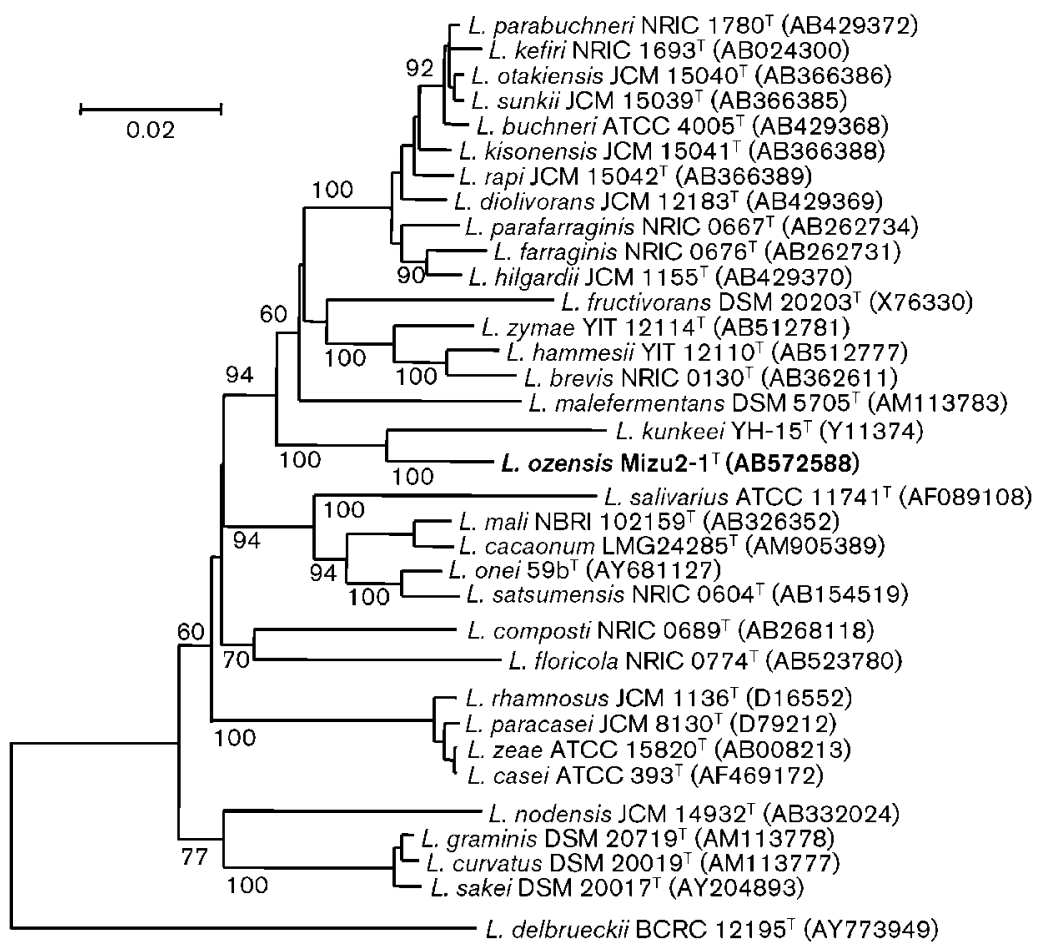

Fig. 1. Phylogenetic tree showing relationships between strain Mizu2-1 ${ }^{\top}$ (Lactobacillus ozensis sp. nov.) and related species. The tree was constructed using the neighbour-joining method based on 16S rRNA gene sequences. Bootstrap values above $50 \%$ are given at branching points. Lactobacillus delbrueckii BCRC $12195^{\top}$ was used as an outgroup. Bar, evolutionary distance $\left(K_{\text {nuc }}\right)$ of 0.02 . 


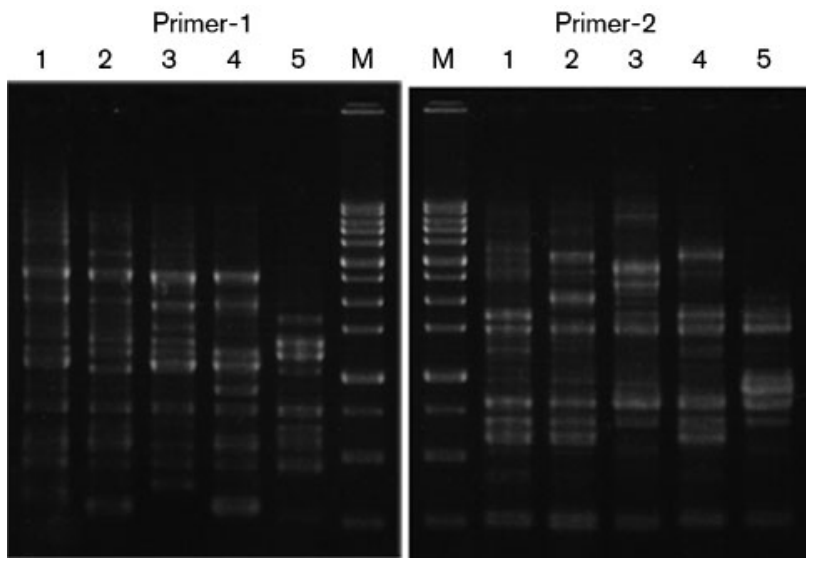

Fig. 2. RAPD-PCR fingerprints of strains of $L$. ozensis sp. nov. Lanes: 1 , Mizu2-1 ${ }^{\top} ; 2$, Gon2-7; 3, Koba6-1; 4, Koyu2-2; 5, Miya22; $\mathrm{M}$, size marker (1 kb ladder; GENECRAFT). Primer-1 and primer-2 were used; see text for details.

Akopyanz et al. (1992) using two primers (primer-1, 5'GAGGACAAAG; primer-2, 5'-GGCATCGGTT) (Morotomi et al., 2002). RAPD-PCR demonstrated genotypic differences (Fig. 2).

Morphological, physiological and biochemical characteristics of the isolates were determined using MRS broth as the basal medium as described previously (Kawasaki et al.,
2011). The detailed characteristics of the isolates are described in the species description. The biochemical characteristics were compared with those of the type strains of the phylogenetic relatives L. kunkeei, L. kefiri, L. floricola and $L$. fructivorans (Table 1 ). The isolates were heterofermentative LAB and produced D- and L-lactic acid from D-glucose, as determined by using L- and D-lactate dehydrogenases (Sigma) (Latorre-Guzman et al., 1977). This finding was confirmed by performing HPLC analysis with a separation column for optical isomers (CRS10W column; Mitsubishi Chemical) (Otsuka et al., 1994; Manome et al., 1998); D- and L-lactic acid were produced at a ratio of $1: 2$. Production of ethanol from glucose was detected by using GC. The strains grew well at 20 and $30{ }^{\circ} \mathrm{C}$ (optimum) and grew slowly at 15 and $37^{\circ} \mathrm{C}$. The strains produced acid from a narrow range of carbohydrates, including glucose and fructose, and produced acid weakly from maltose, sucrose and mannitol.

On the basis of the phenotypic characteristics and phylogenetic data, the isolates represent a novel species, for which the name Lactobacillus ozensis sp. nov. is proposed.

\section{Description of Lactobacillus ozensis sp. nov.}

Lactobacillus ozensis (o.zen'sis. N.L. masc. adj. ozensis of Oze National Park, Japan, from where the first strains were isolated).

Cells are Gram-stain-positive, non-spore-forming, nonmotile rods, $0.5 \times 3-4 \mu \mathrm{m}$, and occur singly, in pairs or in

Table 1. Differential characteristics of strain Mizu2 $-1^{\top}$ (Lactobacillus ozensis sp. nov.) and closely related lactobacilli

Strains: 1 , Mizu2-1 ${ }^{\mathrm{T}}$; 2, L. floricola NRIC $0774^{\mathrm{T}} ; 3$, L. kunkeei DSM $12361^{\mathrm{T}} ; 4$, L. kefiri NRIC $1693^{\mathrm{T}} ; 5$, L. fructivorans NRIC $0224^{\mathrm{T}}$. Data were obtained in this study. +, Positive; -, negative; w, weakly positive. All strains fermented fructose.

\begin{tabular}{|c|c|c|c|c|c|}
\hline Characteristic & 1 & 2 & 3 & 4 & 5 \\
\hline Lactic acid isomer(s) & DL & L & $\mathrm{L}$ & DL & DL \\
\hline Type of fermentation* & Hetero & Homo & Hetero & Hetero & Hetero \\
\hline Arabinose & - & - & - & + & + \\
\hline Cellobiose & - & - & - & - & + \\
\hline Galactose & - & - & - & + & + \\
\hline Maltose & $\mathrm{W}$ & - & - & + & + \\
\hline Mannitol & $\mathrm{W}$ & - & $\mathrm{W}$ & $\mathrm{w}$ & + \\
\hline Mannose & - & - & - & - & + \\
\hline Melezitose & - & - & - & - & + \\
\hline Raffinose & - & - & - & - & + \\
\hline Ribose & - & - & - & $\mathrm{w}$ & + \\
\hline
\end{tabular}

${ }^{\star}$ Homo, Homofermentative; Hetero, heterofermentative.

$\dagger$ Carbohydrate fermentation tests were confirmed by using API 50CHL. Mizu2-1 ${ }^{\mathrm{T}}$ produced acid from D-glucose and D-fructose of the 48 carbohydrates in API 50CHL. 
short chains. Catalase-negative. Colonies develop well on MRS agar plates under anaerobic conditions, and growth is inhibited under aerobic conditions. Colonies on MRS agar are white, smooth and approximately $2 \mathrm{~mm}$ in diameter after incubation for 2 days at $30{ }^{\circ} \mathrm{C}$ under anaerobic conditions. Heterofermentative. Gas is produced from glucose. Both D- and L-lactic acid are produced as end products from D-glucose. Nitrate is not reduced. Acid is produced from D-glucose and D-fructose, and is produced weakly from maltose, sucrose and D-mannitol; no acid production from D-galactose, D-mannose, D-arabinose, D-xylose, melibiose, trehalose, melezitose, D-sorbitol, D-ribose, cellobiose, lactose, raffinose, D-gluconate, Lrhamnose or salicin. Grows at $20-30{ }^{\circ} \mathrm{C}$ and grows slowly at 15 and $37{ }^{\circ} \mathrm{C}$. Grows at $30{ }^{\circ} \mathrm{C}$ in the presence of $1.0 \%$ $(\mathrm{w} / \mathrm{v}) \mathrm{NaCl}$ but not $1.5 \%(\mathrm{w} / \mathrm{v}) \mathrm{NaCl}$. Cells do not contain meso-diaminopimelic acid in their peptidoglycan. The DNA G $+C$ content of the type strain is $41 \mathrm{~mol} \%$.

The type strain is Mizu2- $1^{\mathrm{T}}\left(=\mathrm{JCM} 17196^{\mathrm{T}}=\mathrm{DSM} 23829^{\mathrm{T}}\right)$, isolated from a flower of Inula ciliaris var. glandulosa, a chrysanthemum (Japanese common name oze-mizugiku), that was collected from Oze National Park in August 2008. Four additional strains, Gon2-7 (=JCM 17197), Koba6-1 (=JCM 17198), Koyu2-2 (=JCM 17199) and Miya2-7 (=JCM 17200), are included in this species (details of isolation in legend to Supplementary Fig. S1). All five strains were isolated from mountain flowers in the area of Oze National Park.

\section{Acknowledgements}

We are grateful to Mr Michio Fujita and Ms Kana Hayamidzu, Ministry of Environment, for helpful discussions and sample collection at Oze National Park. We are also grateful to the Agency of Cultural Affairs and the Tokyo Electric Power Company for helpful advice and sample collection at Oze National Park.

\section{References}

Akopyanz, N., Bukanov, N. O., Westblom, T. U., Kresovich, S. \& Berg, D. E. (1992). DNA diversity among clinical isolates of Helicobacter pylori detected by PCR-based RAPD fingerprinting. Nucleic Acids Res 20, 5137-5142.

Cavalli-Sforza, L. L. \& Edwards, A. W. F. (1967). Phylogenetic analysis. Models and estimation procedures. Am J Hum Genet 19, 233-257.

Chao, S. H., Sasamoto, M., Kudo, Y., Fujimoto, J., Tsai, Y. C. \& Watanabe, K. (2010). Lactobacillus odoratitofui sp. nov., isolated from stinky tofu brine. Int J Syst Evol Microbiol 60, 2903-2907.

Edwards, C. G., Haag, K. M., Collins, M. D., Hutson, R. A. \& Huang, Y. C. (1998). Lactobacillus kunkeei sp. nov.: a spoilage organism associated with grape juice fermentations. J Appl Microbiol 84, 698-702.

Felsenstein, J. (1985). Confidence limits on phylogenies: an approach using the bootstrap. Evolution 39, 783-791.
Felsenstein, J. (2005). PHYLIP (Phylogeny Inference Package), version 3.6. Distributed by the author. Department of Genome Sciences, University of Washington, Seattle, USA.

Gerhardt, P., Murray, R. G. E., Costilow, R. N., Nester, E. W., Wood, W. A., Krieg, N. R. \& Phillips, G. B. (1981). Manual of Methods for General Bacteriology. Washington, DC: American Society for Microbiology.

Holdeman, L. V., Cato, E. P. \& Moore, W. E. C. (1977). Anaerobe Laboratory Manual. Blacksburg, VA: Virginia Polytechnic Institute and State University.

Kawasaki, S., Kurosawa, K., Miyazaki, M., Yagi, C., Kitajima, Y., Tanaka, S., Irisawa, T., Okada, S., Sakamoto, M. \& other authors (2011). Lactobacillus floricola sp. nov., lactic acid bacteria isolated from mountain flowers. Int J Syst Evol Microbiol 61, 1356-1359.

Kimura, M. (1980). A simple method for estimating evolutionary rates of base substitutions through comparative studies of nucleotide sequences. J Mol Evol 16, 111-120.

Kluge, A. G. \& Farris, J. S. (1969). Quantitative phyletics and the evolution of the anurans. Syst Zool 18, 1-32.

Lane, D. J., Pace, B., Olsen, G. J., Stahl, D. A., Sogin, M. L. \& Pace, N. R. (1985). Rapid determination of $16 S$ ribosomal RNA sequences for phylogenetic analyses. Proc Natl Acad Sci U S A 82, 6955-6959.

Latorre-Guzman, B. A., Kado, C. I. \& Kunkee, R. E. (1977). Lactobacillus hordniae, a new species from the leafhopper (Hordnia circellata). Int J Syst Bacteriol 27, 362-370.

Manome, A., Okada, S., Uchimura, T. \& Komagata, K. (1998). The ratio of $\mathrm{L}$-form to $\mathrm{D}$-form of lactic acid as a criteria for the identification of lactic acid bacteria. J Gen Appl Microbiol 44, 371-374.

Mesbah, M., Premachandran, U. \& Whitman, W. B. (1989). Precise measurement of the $\mathrm{G}+\mathrm{C}$ content of deoxyribonucleic acid by highperformance liquid chromatography. Int J Syst Bacteriol 39, 159-167.

Morotomi, M., Yuki, N., Kado, Y., Kushiro, A., Shimazaki, T., Watanabe, K. \& Yuyama, T. (2002). Lactobacillus equi sp. nov., a predominant intestinal Lactobacillus species of the horse isolated from faeces of healthy horses. Int J Syst Evol Microbiol 52, 211-214.

Naser, S. M., Thompson, F. L., Hoste, B., Gevers, D., Dawyndt, P., Vancanneyt, M. \& Swings, J. (2005). Application of multilocus sequence analysis (MLSA) for rapid identification of Enterococcus species based on rpoA and pheS genes. Microbiology 151, 2141-2150.

Okada, S., Uchimura, T. \& Kozaki, M. (1992). Laboratory Manual for Lactic Acid Bacteria. Tokyo: Asakura-shoten (in Japanese).

Otsuka, M., Okada, S., Uchimura, T. \& Komagata, K. (1994). A simple method for the determination of stereoisomers of lactic acid by HPLC using an enantiomeric resolution column, and its application to identification of lactic acid bacteria. Seibutsu-kogaku Kaishi 72, 81-86 (in Japanese).

Saitou, N. \& Nei, M. (1987). The neighbor-joining method: a new method for reconstructing phylogenetic trees. Mol Biol Evol 4, 406-425.

Stackebrandt, E. \& Goebel, B. M. (1994). Taxonomic note: a place for DNA-DNA reassociation and $16 \mathrm{~S}$ rRNA sequence analysis in the present species definition in bacteriology. Int J Syst Bacteriol 44, 846-849.

Thompson, J. D., Gibson, T. J., Plewniak, F., Jeanmougin, F. \& Higgins, D. G. (1997). The CLUSTAL_X windows interface: flexible strategies for multiple sequence alignment aided by quality analysis tools. Nucleic Acids Res 25, 4876-4882. 